\title{
The Inhibition Activity of Tannin on the Formation of Mono-Species and Polymicrobial Biofilm Escherichia coli, Staphylococcus aureus, Pseudomonas aeruginosa, and Candida albicans
}

\author{
Hasyrul Hamzah ${ }^{1}$, Triana Hertiani ${ }^{1}{ }^{*}$, Sylvia Utami Tunjung Pratiwi ${ }^{1}$, Titik Nuryastuti ${ }^{2}$ \\ ${ }^{1}$ Faculty of Pharmacy, Universitas Gadjah Mada, Yogyakarta \\ ${ }^{2}$ Faculty of Medicine, Public Health, and Nursing, Universitas Gadjah Mada, Yogyakarta
}

\begin{abstract}
Biofilm acts as the mediator for infection nowadays. Approximately, more than $80 \%$ infection incidents are biofilm-formation related. Biofilm as bacteria's defense system is more difficult to eradicate by antibiotic; therefore, pathogen bacteria on their biofilm forms can make serious problems for human health. The invention of a new candidate for polymicrobial biofilm can be an essential challenge to be studied, in order to prevent infections related to biofilm. Tannin is a polyphenol compound with antibacterial and anti-fungal potential. This study aims to acknowledge the effectiveness of tannin in inhibition and degradation of $C$. albicans, P. aeruginosa, E. coli, S. aureus, and polymicrobial biofilm. The assay for biofilm inhibition and degradation were determined with microtiter broth method. The effectivity of tannin antibiofilm against polymicrobial biofilm were analyzed by calculating minimum biofilm inhibitory concentration $\left(\mathrm{MBIC}_{50}\right)$ and minimum biofilm eradication concentration $\left(\mathrm{MBEC}_{50}\right)$ values. The mechanism of action of tannin against polymicrobial biofilm was tested using scanning electron microscopy (SEM). The data were analyzed using the Statistical Package for the Social Sciences (SPSS) with a 95\% confidence level. Tannin $1 \%$ gave inhibition activity of mono-species biofilm formation $S$. aureus in the middle phase and maturation of $79.04 \pm 0.01,61.48 \pm 0.03$, E. coli $74.56 \pm 0.01,67.91 \pm 0.02$, P. aeruginosa $67.32 \pm 0.05,35.13 \pm$ 0.01 , C. albicans $60.62 \pm 0.01,47.16 \pm 0.01$. The results also provide evidence that tannin activity can degrade and damage the matrix of extracellular polymeric substance (EPS) polymicrobial biofilms. Hence, tannins can be a potential candidate for new antibiofilm for polymicrobial biofilm.
\end{abstract}

Keywords: Mono-species biofilm, Polymicrobial biofilm, Tannin, SEM

\section{INTRODUCTION}

There is an urgency on anti-biofilm agent development, for traditionally speaking, natural products have provided some antimicrobial compounds in general and medication for infection in particular, Biofilm is one heterogenous community from a microorganism that attaches on the abiotic or biotic surface, and it is covered in the extracellular matrix, forming a complex 3D structures (Andersson et al., 2009).

Further problems related to microbialinside-biofilm management is the diversity of the microbes forming the biofilm polymicrobial (Donlan, 2002). Microbial biofilm can act as the defense part so that the microbes that form biofilm could be resistant towards common antimicrobial agents, and it could avoid from the host's immune system. Biofilm could grow as the clinical infection on the host cell increase. Therefore, this biofilm is one of the factors for virulence and resistance (Pratiwi and Hertiani, 2015.). The demands for novel anti-microbial agents are now increasing significantly (Prakash et al., 2003).

\footnotetext{
*Corresponding author : Triana Hertiani
}

Email : hertiani@ugm.ac.id
Disinfectant can effectively kill planktonic cells, with all disinfectant can reduce $>99,999 \%$ inside the amount of the cells, yet only little disinfectant could maintain this high effectiveness if applied on mono-species or multi-species biofilm. Another data showed that multi-species biofilm is usually less resistant against anti-microbial substance compared to monospecies biofilm (Harriott and Noverr, 2010).

Recently, there has been a growing interest in the discovery of GRAS (generally regarded as safe) compounds from natural substances to combat new and existing diseases. Higher plants are attractive species for this discovery because they contain an abundance of potentially active secondary metabolites (Chen et al., 2013).

The previous study showed that tannin had an antimicrobial activity for mono-species (Akiyama et al., 2001). Despite of being potential as antibiofilm against single species microbes, there is no reports on their effects tannin against polymicrobial biofilms consisted of $P$. aeruginosa, E. coli, S. aureus, C. albicans. Research on such a topic is essential to evaluate the effectiveness of tannin, as antibiofilm in polymicrobial cultures. 


\section{METHODOLOGY \\ Materials}

Tannin is collected from Pharmacy-Biology Laboratory, Faculty of Pharmacy, UGM, Yogyakarta, Indonesia. Other materials include the following: crystal violet (Merck, Germany), ethyl acetate (Merck, Germany), Brain heart infusion (Oxoid) (Merck, Germany), RPMI 1640 (SigmaAldrich), ethanol 95 \% (Merck, Germany), nystatin, chloramphenicol (Sigma-Aldrich, Germany).

\section{Methods \\ Bacterial Strains}

A standard strain of Staphylococcus aureus (ATCC 25923), Escherichia coli (ATCC 25922), Pseudomonas aeruginosa (ATCC 27853), was cultured in tryptic soy broth (TSB) medium and incubated at $37^{\circ} \mathrm{C}$ for $72 \mathrm{~h}$. Candida albicans (ATCC 10231) was cultured in Sabouraud Dextrose Broth (SDB) medium and incubated at $37^{\circ} \mathrm{C}$ with agitation at $(120 \mathrm{rpm})$ for $24 \mathrm{~h}$. The optical densities $\left(\mathrm{OD}_{600}\right)$ of microbial cultures will be adjusted to 0.1 (equal of the 0.5 McFarland standard $\sim 1,5 \times 10^{8} \mathrm{CFU} / \mathrm{ml}$ ), and subsequently diluted in fresh medium to $\mathrm{OD}_{600} 0.01$ for each microbial species.

\section{Biofilm Formation Inhibition and Biofilm Eradication Assay in Vitro}

In order to determine the isolate tannin activity toward formation and degeneration of biofilm, a microtiter plate polystyrene flat-bottom 96-well was used (Pierce et al., 2010). A $100 \mu \mathrm{L}$ of C. albicans suspension $\left(10^{7} \mathrm{CFU} / \mathrm{mL}\right)$ was inserted in each good microtiter plate, C. albicans were incubated at $37^{\circ} \mathrm{C}$ for 90 minutes for biofilmadhesion phase. After the incubation, plates were washed using $150 \mu \mathrm{L}$ of sterile aquadest three times in order to nullify the non-adhesive cells. A $100 \mu \mathrm{L}$ of media contained tannin with different concentrations $(1 \% \mathrm{~b} / \mathrm{v}, 0,5 \% \mathrm{~b} / \mathrm{v}, 0,25 \% \mathrm{~b} / \mathrm{v}$, $0,125 \% \mathrm{~b} / \mathrm{v}$ ), was added to each washed-well. Media with methanol were used as diluting control, and microbe suspensions were used as negative control. As the positive control, a microbe suspension with nystatin $1 \%$ was used, and a media without microbe growth was used as media control. The plates were incubated in $37^{\circ} \mathrm{C}$ for 24 hours to form the mid-phase biofilm and 48 hours for maturating phase. Plates were washed with distilled water three times. A $125 \mu \mathrm{L}$ solution of crystal violet $1 \%$ was added to each well in order to color the formed biofilm. The plates were incubated in room temperature for 15 minutes.
After incubation, the microplates were washed with running water three times to clean the crystal violet's remains and A $200 \mu \mathrm{L}$ of ethanol 96\% was added to each well. The Optical Density (OD) reading was performed with microplate reader on the wavelength of $595 \mathrm{~nm}$. The testing was performed in three times replication. The percentage of inhibition and degeneration for every tannin concentration was counted using the formula below:

Od growth control - Od sample / Od growth control x 100

The amount of sample that could inhibit at least $50 \%$ of the biofilm formation can be considered as minimum biofilm inhibitory concentration $\left(\mathrm{MBIC}_{50}\right)$ and minimum biofilm eradication concentration (MBEC50) (Pratiwi and Hertiani, 2017). The testing for polymicrobial biofilm C. albicans, E. coli, P. aeruginosa and $S$. aureus was performed under the same methods with the monospecies $C$. albicans. In another hand, the biofilm testing towards $E$. coli, $P$. aeruginosa and $S$. aureus was similar to the monospecies testing without incubation of $\mathrm{C}$. albicans at $\pm 37^{\circ} \mathrm{C}$ for 90 minutes for adhesion phase. A microbial suspension that already given an antibiotic namely chloramphenicol $1 \% \mathrm{~b} / \mathrm{v}$ was used as controlantibiotic.

\section{Biofilm structure documentation using SEM}

The coverslip was inserted inside the microtiter plate round bottom polystyrene 24 well that contained testing suspension that had been given a similar treatment with biofilm inhibition assay. The coverslips were then incubated on $37^{\circ} \mathrm{C}$ for 24-48 hours, continued to the careful washing of the coverslip for three-time with sterile aquadest, then fixated with 2,5 \% (b/v) glutaraldehyde inside cacodylate buffer for \pm 24 hours with the aim of cell's death without changing the cell's structure that will be observed. Next, a dehydration process using methanol was done for 30 minutes in order to minimize the water amount so that the observing process could not be interrupted. The sample then observed under Scanning Electron Microscopy (SEM) with a voltage of $10 \mathrm{Kv}$ (Hess et al., 2012).

\section{Statistical methods:}

Statistical significance of the data was determined using ANOVA, followed by Normality test using the Shapiro - Wilk test. Differences were considered significant with $P$ values of 0.05 or less (Hamzah et al., 2018). 
Table I. Effect of Tannin against Mono-Species Mid - Phase Biofilm (24h).

\begin{tabular}{lllc}
\hline Compound & Bacterial strains & \% Inhibition & MBIC 50 b/v \\
\hline Tannin 1\% & S. aureus & $79.04 \pm 0.01^{*}$ & $0.5 \%$ \\
& E. coli & $74.56 \pm 0.35^{*}$ & $0.125 \%$ \\
& P. aeruginosa & $67,32 \pm 0.05^{*}$ & $0.25 \%$ \\
& C. albicans & $60.62 \pm 0.01^{*}$ & $0.5 \%$ \\
Chloramphenicol 1\% & S. aureus & $81.63 \pm 0.01^{*}$ & $0.25 \%$ \\
& E. coli & $77.95 \pm 0.01^{*}$ & $0.25 \%$ \\
Nystatin 1\% & P. aeruginosa & $88.76 \pm 0.01^{*}$ & $0.25 \%$ \\
\hline
\end{tabular}

$\left.{ }^{*}\right)$ significance correlation ( $P$ value $\left.<0.05\right)$, MBIC: Minimum biofilm inhibitory concentration. Mono-spesies biofilm consist of S. aureus - P. aureginosa - E. coli and C. albicans

\section{RESULT AND DISCUSSION}

Effect of tannin against mono-species midphase biofilm (24h)

Biofilm is one of the severe health problems related to infection's prevention (Donlan, 2002). Bacteria can synergistically form a biofilm with other bacteria with different species, and the biofilm structure is stronger and thicker physically and physiologically (Huang et al., 2015; Yadav and Jha, 2015). On this study, we evaluate tannin potential in the inhibition of monospecies biofilms such as P. aeruginosa, E. coli, $S$. aureus, and C. albicans. The result showed that tannin could inhibit $50 \%$ of biofilm formation (mono-species and polymicrobial biofilm) (Table I).

Tannin inhibition of $S$. aureus gave the highest activity of $79.04 \pm 0.01$ and was better than inhibition of $E$. coli bacteria $74.56 \pm 0.01, P$. aeruginosa $67.32 \pm 0.01$ and C. albicans $60.62 \pm$ 0.01 , so the activity is more compared to drug control (chloramphenicol) (Table 1). MBIC50 activity from tannin in the middle phase for $\mathrm{S}$. aureus species at levels of $0.5 \mathrm{~b} / \mathrm{v}, E$. coli at levels of $0.125 \% \mathrm{~b} / \mathrm{v}, P$. aeruginosa $0.25 \% \mathrm{~b} / \mathrm{v}$ and $C$. albicans $0.5 \% \mathrm{~b} / \mathrm{v}$.

Biofilm inhibition mechanism and planktonic-inhibition mechanism were different; in biofilm, bacteria altogether formed a group or community, resulted in a stronger defense that is more complex and stronger, while on planktonic, bacteria were only one single cell and life freely so that antimicrobial agents could cause more natural damage the defense's cell and reaching the target cells.

The biofilm structure consists of $97 \%$ water, $2-5 \%$ microbe cells, 3-6\% EPS, and ions, and it has fixed structure that formed an optimal environment for the genetic material exchange between cells (Leriche et al., 2003).
Planktonic cells are cultured cells that grown as single-cell and life freely (Hall-Stoodley et al., 2004). Most of the biofilm are from nature, more resistant to the environment and antimicrobial agents compared to planktonic cells (Huang et al., 2015).

\section{Effect of Tannin against mid-phase polymicrobial biofilm $(24 \mathrm{~h})$.}

Natural Polymicrobial biofilms are formed from endogenous microbiota members and nosocomial pathogen (Andersson et al., 2009). Microorganism commonly attached to the solid' surface and formed biofilm (Qureshi et al., 2005). Tannin 1\% shown an inhibition activity towards polymicrobial biofilm on 24 hours phase (Figure 1).

This shows that compound can break the polymicrobial biofilm's mucus. On the control group chloramphenicol (69.82 \pm 0.01$)$, the inhibitory activity given was not significantly different from the inhibitory activity of tannin $1 \%$ $(60.44 \pm 0.01)$, while on nystatin control group nystatin $(55.70 \pm 0.01)$ the inhibition activity given is lower compared to tannin $1 \%$.

Biofilm compound can be more resistant caused by the more complex matrix composition, this can be identified by the antibiotic' resistance that changed on the mixed infection.

On polymicrobial biofilm, there are eukaryotic and prokaryotic pathogens; because of that, this biofilm is harder to diagnose, and it needed a complex multi-drug medication strategy (Harriott and Noverr, 2010). Antibiotic and several antimicrobial agents need 10-1000 times higher concentration in order to inhibit the formation and degrades biofilm compared to planktonic cells (Bjarnsholt et al., 2007). 


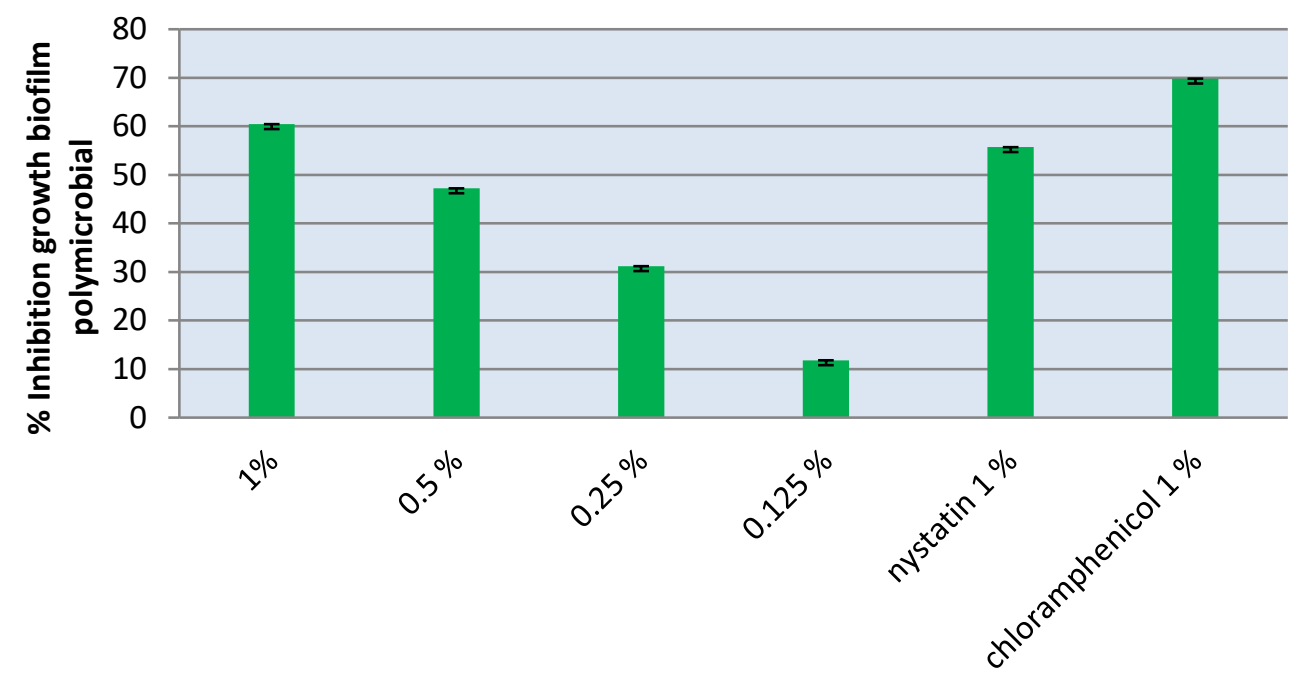

Figure 1. Effect of Tannin against Mid - Phase Polymicrobial Biofilm (24 H).

Table II. Effect of Tannin against Mono-Species Biofilm Maturation Phase (48 H)

\begin{tabular}{llcc}
\hline Compound & Bacterial strains & \% Inhibition & MBIC $5 \mathbf{b} \mathbf{b} \mathbf{v}$ \\
\hline Tannin 1\% & S. aureus & $61.48 \pm 0.03^{*}$ & $0.5 \%$ \\
& E. coli & $67.91 \pm 0.02^{*}$ & $0.5 \%$ \\
& P. aeruginosa & $35.13 \pm 0.01^{*}$ & - \\
Chloramphenicol 1 \% & C. albicans & $47.16 \pm 0.01^{*}$ & - \\
& S. aureus & $79.49 \pm 0.01^{*}$ & $0.25 \%$ \\
& E. coli & $81.84 \pm 0.01^{*}$ & $0.25 \%$ \\
Nystatin 1\% & P. aeruginosa & $79.66 \pm 0.01^{*}$ & $0.25 \%$ \\
\hline
\end{tabular}

*) significance correlation $(P$ value $<0.05)$, MBIC: Minimum biofilm inhibitory concentration. Mono-spesies biofilm consist of S. aureus - P. aureginosa - E.coli and C. albicans

\section{Effect of Tannin against mono-species biofilm maturation phase $(48 \mathrm{~h})$ \\ On the maturation phase, anti-microbial} agents will have more difficulties to break the biofilm's defense (Hamzah et al., 2018). Biofilm formation on the 48-hour phase is excited with the growth of advance hyphae and extracellular polymeric substance (EPS) production, that consisted of polysaccharide cell walls and protein. Adult biofilm consisted of yeast with hyphae substance that forms complex networks that covered in EPS and away from the surface (Harriott and Noverr, 2010).

Tannin causes $50 \%$ damage in the maturation phase of mono-species E. Coli and $S$. aureus. Antibiotic activity of chloramphenicol and nystatin used as drug control showed inhibitory activity better than tannin $1 \%$ against $P$. aeruginosa and S. aureus, E. coli and C. albicans (Table II).

At this phase, biofilm's protection system was already strong and thick, and it had been built inter-cellular communication among the bacteria that formed biofilm; bacteria can synergistically form thick and thicker biofilm, and in this phase, biofilm could trick antibiotic, while it could pretend to die when antibiotic was discovered on biofilm, yet when the antibiotic was stopped, the biofilm will grow back forming a planktonic that will be built a new biofilm community. Compared to the previous 24 hours phase when biofilm had not had that synergistically with one another, they only built biofilm communities with not so strong layers so that antibiotic could break the biofilm defense. The 48 hours phase built a strong defense system and built communication mechanism called quorum sensing. This made antibiotic having a hard time to killed and damaged the bacteria that built biofilm (Hamzah et al., 2018).

\section{Effect of Tannin against polymicrobial biofilm phase ( $48 \mathrm{~h})$}

The interaction between species played a role in colonization and infection dynamics and other several responses. Infection that caused by 


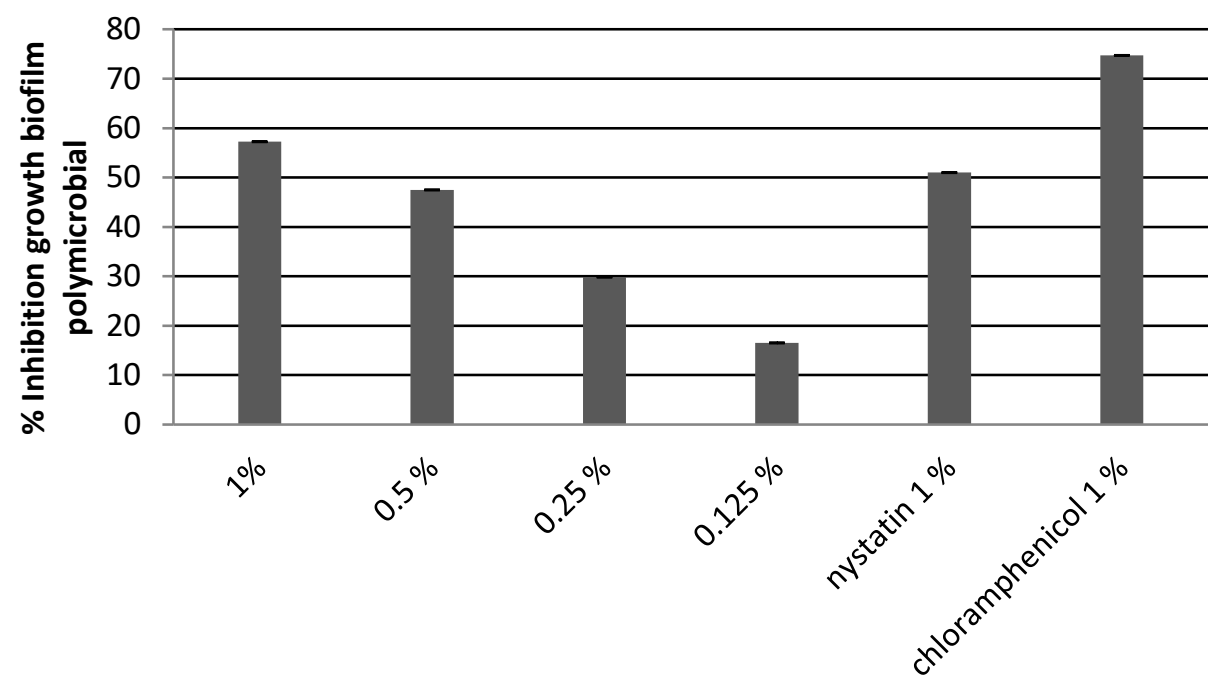

Figure 2. Effect of Tannin against maturation-phase Biofilm Polymicrobial

biofilm resistance could cause the exacerbation of the infection, prolonged infection, and the increased of the costs, and high death rate (Harriott and Noverr, 2010). The results were described in Fig 2, shown that tannin compound had inhibition activity on polymicrobial biofilm $\left({ }^{*} P<0.05\right)$ (Figure 2).

This result showed that control drug chloramphenicol better than that inhibition activity tannin compound, while nystatin has a lower inhibition activity than tannins. On the 48hours phase, polymicrobial inhibition, tannin, and the control drugs had a harder time to broke and damaged the biofilm defense system, caused by a 3D structure that was harder to be broken.

The biofilm made by several microorganisms can differ according to EPS, low growth rate, and the fluctuated gene regulation (Andersson et al., 2009). Multispecies Microorganism community are the main structure of biofilm formation in nature, where each microorganism species placed an ecological niche in the biofilm that suited their morphology and metabolism ability (Banin et al., 2005).The biofilm made by several microorganisms can differ according to EPS, low growth rate, and the fluctuated gene regulation (Andersson et al., 2009). Multispecies Microorganism community are the main structure of biofilm formation in nature, where each microorganism species placed ecological niche in the biofilm that suited their morphology and metabolism ability (Banin et al., 2005).

\section{Effect of Tannin against polymicrobial biofilm phase eradication}

EPS Matrix on biofilm could built microorganism to survive longer compared to when they were in the planktonic condition so that they could help the micro consortium of several microorganism species in order to complete degradation process (Donlan and Costeron, 2002). We reported that tannin $1 \%$ could degrade biofilm for $50 \%$.

This shown that tannin 1\% could damage the defense of polymicrobial biofilm formation polymicrobial S. aureus, P. aeruginosa, E. coli, and C. albicans, these compounds could break the communication cells among the bacteria and fungi so the biofilm growth could mean reduced. On the drug control chloramphenicol, the inhibition activity that gave on degradation phase polymicrobial biofilm was higher than tannin while on drug control nystatin the inhibition activity was lower when it compared to tannin $1 \%$.

On this phase, the inhibition activity that obtained was lower compared to the 24-hours phase inhibition (mid-phase) and 48 hours phase (maturation). This caused by, on degradation phase, the synergy amongst the bacteria that form biofilm was longer, so that the communication among them was more complex and organized one another, lead to thicker and stronger biofilm. The defense for mucus layer that made from biofilmforming bacteria was more abundant and thicker on this degradation phase so that antibiotics had hard times to penetrate the biofilm 


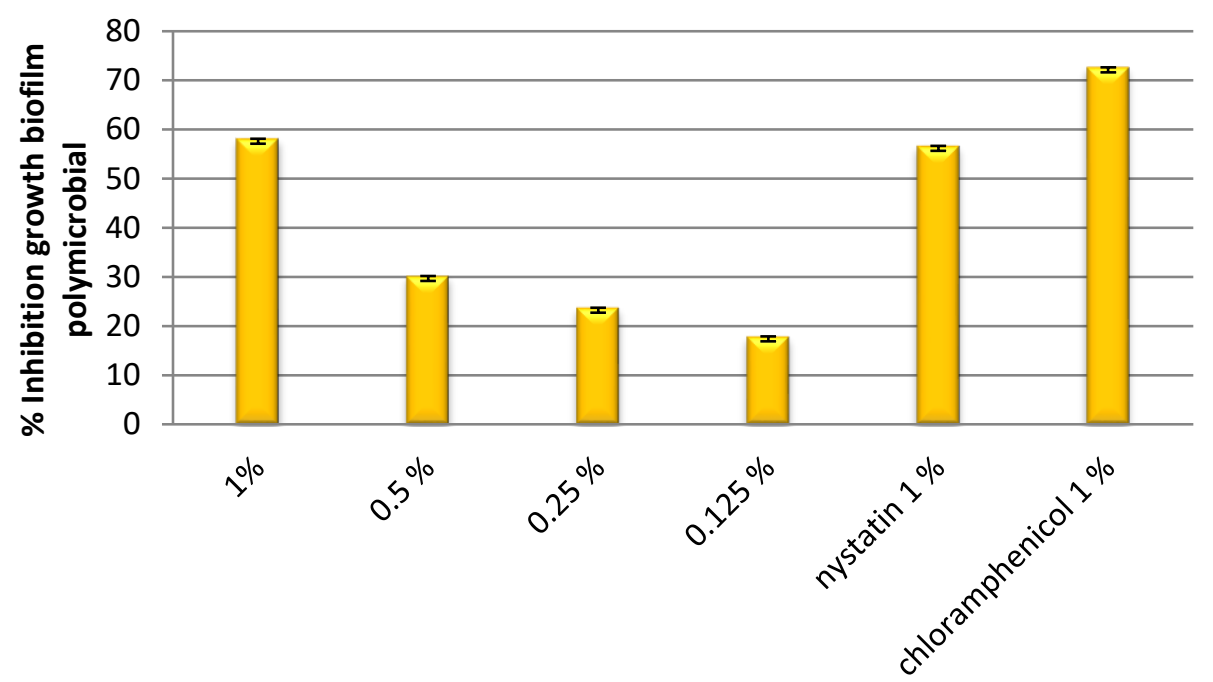

Figure 3. Effect of Tannin against polymicrobial eradication biofilm

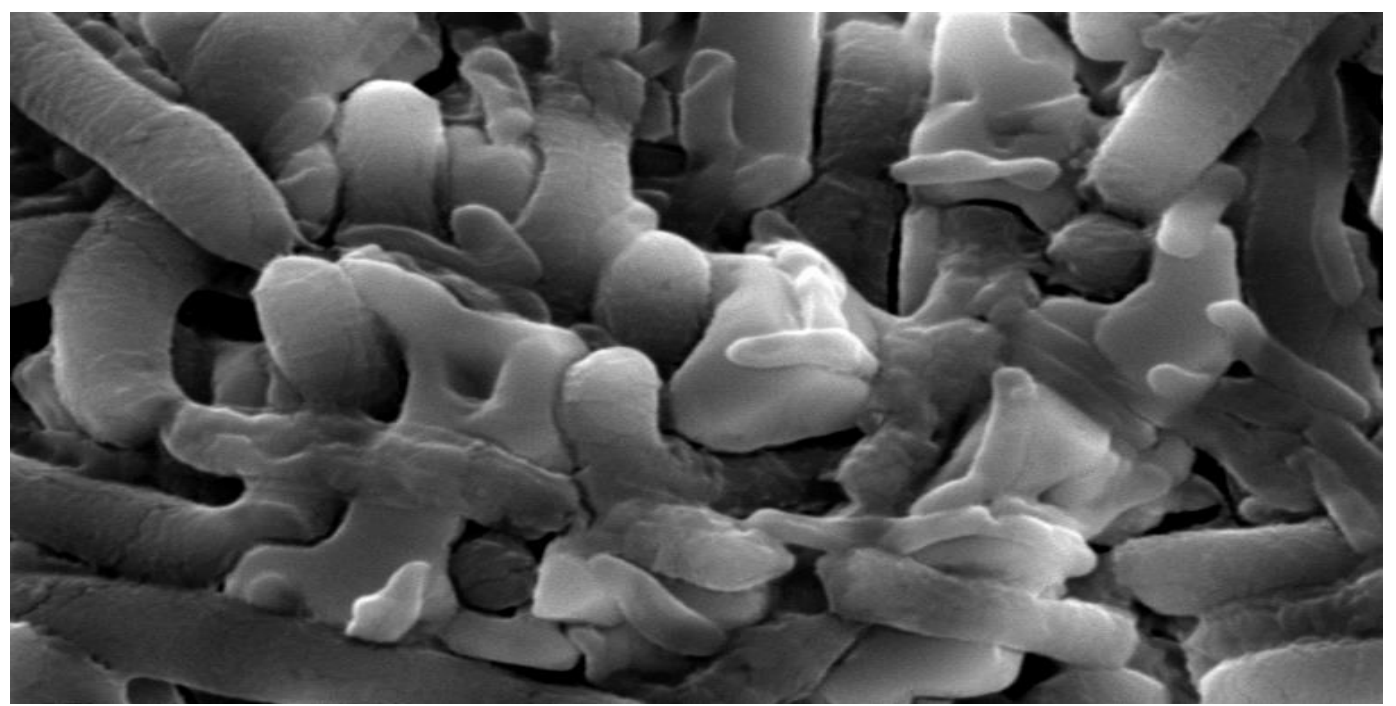

images are taken using Scanning Electron Microscopy with an X 10,000 magnification

Figure 4. SEM visualization of Biofilm polymicrobial S. aureus - P. aureginosa - E.coli and C. albicans without treatment.

defense and they could not reach the target cells; with the active and involved biofilm, this caused the increase of resistance incidences compared to antibiotics that inhibit and damaged the planktonic cells.

The degradation phase was harder when it comes to damage the biofilm, compared to the microbe that formed biofilm in the mid and inhibition phase. This caused by the longer the biofilm growth time, the joint venture among the bacteria community was stronger, so the antibiotic was hard to penetrate (Hamzah et al., 2018). Biofilm in nature consists of a mixture of various strain and even various species of microbes living together. The microbial diversity in polymicrobial biofilms adds complexity in the eradication process (Li u et al., 2000).

C.albicans and S.aureus formed a polymicrobial biofilm that complexes inside the serum. Although S.aureus built little mono-species biofilm inside the serum, it could be built bigger polymicrobial biofilm with the existence of C.albicans (Harriott and Noverr, 2010).

The MBIC $_{50}$ values given by tannin $1 \% \mathrm{~b} / \mathrm{v}$ $\left({ }^{*} P<0.05\right)$. This result was reported as the inhibition of polymicrobial biofilm on the 


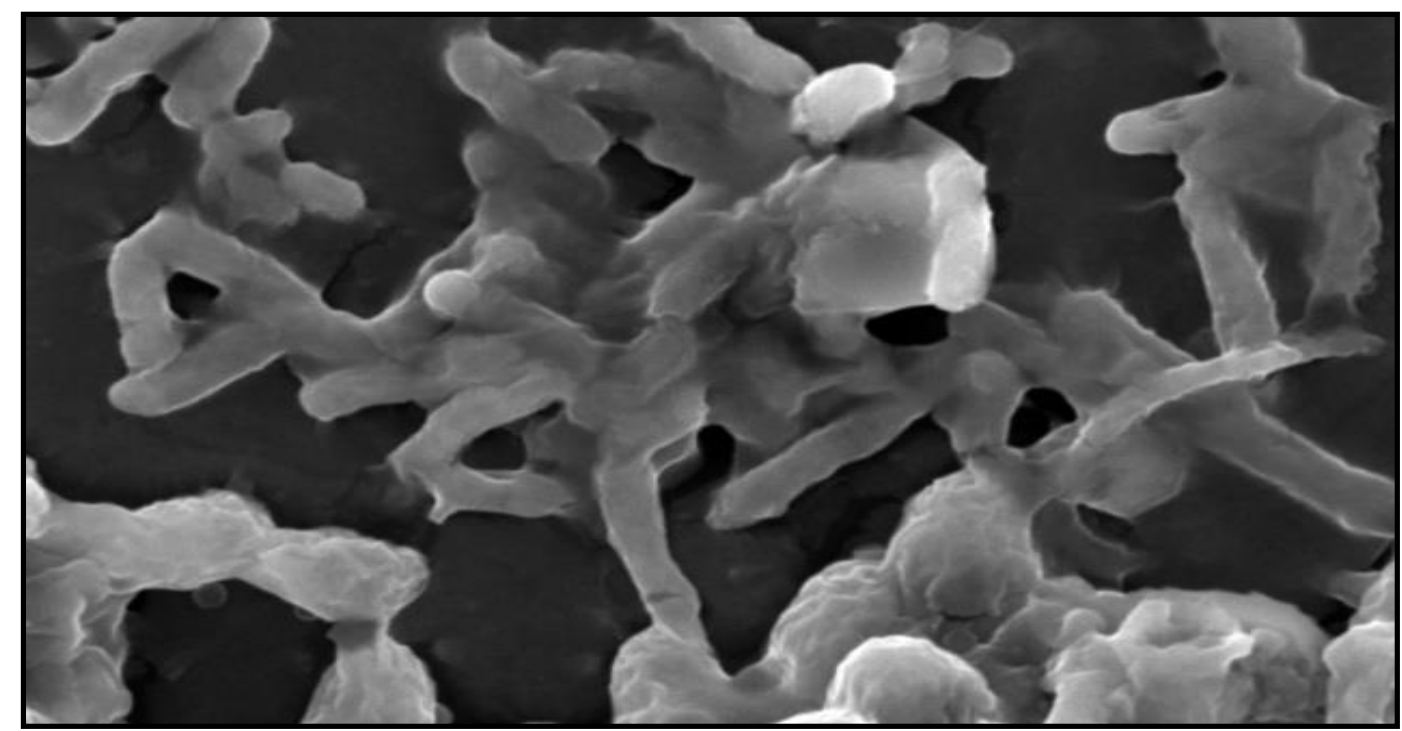

images are taken using Scanning Electron Microscopy with an X 10,000 magnification

Figure 5. SEM visualization of tannin $0,25 \% \mathrm{~b} / \mathrm{v}$

degradation phase, tannin worked better than nystatin control, y but with chloramphenicol control, the inhibition activity was better compared to tannin. Therefore effectiveness of tannin against polymicrobial biofilm is an interesting thing to the discovery of new antibiofilm compounds as a therapeutic option for biofilm polymicrobial related infections.

\section{The Result of Scanning Electron Microscopy Polymicrobial Biofilm with No Treatment}

Polymicrobial biofilm $P$. aeruginosa - $C$. albicans - S. aureus - C. albicans that given no treatment showed a thicker cell, involved and had a dense cell and it showed an EPS production (Figure 4).

In this picture, we can see the bindings between one bacterium to other bacteria were secure so the biofilm formed was strong. This caused by bacteria could synergistically form a biofilm with other species, and physically and physiologically the biofilm structure was more thick and stronger (Cowan et al., 2000). C. albicans had a protecting effect on S.aureus by covering S.aureus with a matrix that is secreted (Sangetha et al., 2009).

The Result of Scanning Electron Microscopy on Polymicrobial Biofilm with Tannin $0.25 \% \mathrm{~b} / \mathrm{v}$

The giving of tannin $0,25 \% \mathrm{~b} / \mathrm{v}$ compound (figure 5) on polymicrobial biofilm P. aeruginosaE. coli - C. albicans - S. aureus caused a decrease in the number of cell attachments and densities, and the inhibition of biofilm formation carried out in consideration of lysis involves involving active complications that attack EPS which are protective for biofilms.

\section{CONCLUSION}

Tannin inhibits mono-species growth and polymicrobial biofilm. This can destroy the matrix EPS (Extracellular polymeric substances) polymicrobial biofilm. Therefor can be potential sources of novel antibiofilm candidates against polymicrobial biofilms $P$. aeruginosa - E coli - $S$. aureus and $C$. albicans.

\section{ACKNOWLEDGMENT}

Authors acknowledge Education Fund Management Institution Scholarship (LPDP) for research financial support.

\section{REFERENCES}

Adhirajan, N., Kumar, Andersson, S., Dalhammar, G., Land, C.J., Kuttuva Rajarao, G., 2009. Characterization of extracellular polymeric substances from denitrifying organism Comamonas denitrificans. Appl. Microbiol. Biotechnol. 82, 535-543. https://doi.org/10.1007/s00253-0081817-3

Banin, E., Vasil, M.L., Greenberg, E.P., 2005. Iron and Pseudomonas aeruginosa Biofilm Formation. Proc. Natl. Acad. Sci. U. S. A. 102, 11076-11081.

Bjarnsholt, T., Kirketerp-Møller, K., Kristiansen, S., Phipps, R., Nielsen, A.K., Jensen, P.Ø., Høiby, N., Givskov, M., 2007. Silver against 
Pseudomonas aeruginosa biofilms. APMIS

115, 921-928.

https://doi.org/10.1111/j.16000463.2007.apm_646.x

Chen, M., Yu, Q., Sun, H., 2013. Novel Strategies for the preventation and Treatment of Biofilm Related Infections. Int. J. Mol. Sci. 14, 1848818501. https://doi.org/10.3390/ijms140918488

Cowan, S.E., Gilbert, E., Liepmann, D., Keasling, J.D., 2000. Commensal Interactions in a DualSpecies Biofilm Exposed to Mixed Organic Compounds. Appl. Environ. Microbiol. 66, 4481-4485.

Donlan, R., Costeron, J., 2002. Biofilm: Survival Mechanism of Clinically relevant Microorganism.Clin Microbial Rev.

Donlan, R.M., 2002. Biofilms: Microbial Life on Surfaces. Emerg. Infect. Dis. 8, 881-890. https://doi.org/10.3201/eid0809.020063

Hamzah, H., Pratiwi, S.U.T., Hertiani, T., 2018. Efficacy of Thymol and Eugenol Against Polymicrobial Biofilm. E Coli 29, 8.

Harriott, M.M., Noverr, M.C., 2010. Ability of Candida albicans Mutants To Induce Staphylococcus aureus Vancomycin Resistance during Polymicrobial Biofilm Formation. Antimicrob. Agents Chemother. 54, 3746-3755. https://doi.org/10.1128/AAC.00573-10

Hess, D.J., Henry-Stanley, M.J., Barnes, A.M.T., Dunny, G.M., Wells, C.L., 2012. Ultrastructure of a Novel Bacterial Form Located in Staphylococcus aureus In Vitro and In Vivo Catheter-Associated Biofilms. J. Histochem. Cytochem. 60, 770-776.

Huang, W., Duan, Q., Li, F., Shao, J., Cheng, H., Wu, D., 2015. Sodium houttuyfonate and EDTA-Na2 in combination effectively inhibits Pseudomonas aeruginosa, Staphylococcus aureus and Candida albicans in vitro and in vivo. Bioorg. Med. Chem. Lett. 25, 142-147.

Leriche, V., Briandet, R., Carpentier, B., 2003. Ecology of mixed biofilms subjected daily to a chlorinated alkaline solution: spatial distribution of bacterial species suggests a protective effect of one species to another. Environ. Microbiol. 5, 64-71.

Liu H, Xu L, Zeng J. (2000). Role of Corrosion Products in Biofilms in Microbiologically Induced Corrosion of Carbon Steel. British Corr J 35, 131-135

Pierce, C.G., Uppuluri, P., Tummala, S., Lopez-Ribot, J.L., 2010. A 96 well microtiter plate-based method for monitoring formation and antifungal susceptibility testing of Candida albicans biofilms. J. Vis. Exp. JoVE.
Prakash, B., Veeregowda, B.M., Krishnappa, G., 2003. Biofilms: a survival strategy of bacteria. Curr. Sci. 85, 1299-1307.

Pratiwi, S.U.T., Hertiani, T., 2017. Efficacy of massoia oil in combination with some indonesian medicinal plants oils as antibiofilm agent towards candida albicans. Int. J. Pharm. Sci. Res. 8, 13.

Yadav, A., Jha, S., n.d. To study the effect of guava leaf extract on biofilm formation in 7 .

Sangetha, S., Zuraini, Z., Suryani, S., dan Sasidharan, S. (2009.) In situ TEM and SEM studies on the antimicrobial activity and prevention of Candida albicans biofilm by Cassia spectabilis extract. Micron (Oxford, England: 1993), 40, 439-443.

Qureshi, N., Annous, B.A., Ezeji, T.C., Karcher, P., dan Maddox, I.S. (2005). Biofilm Reactors for Industrial Bioconversion Processes: Employing Potential of Enhanced Reaction Rates. Microbial Cell Factories, 4, 24.

D.V. \& Gowri, C., 2008, 'Development and Evaluation of Herbal Formulations for Hair Growth', E-Journal Chem. 5, 34-38.

Departemen Kesehatan Republik Indonesia, 1995, Farmakope Herbal Indonesia, $1^{\text {st }}$ ed, pp. 6, Direktur Jendral Badan Pengawas Obat dan Makanan, Jakarta.

Departemen Kesehatan Republik Indonesia, 2000, Parameter Standar Umum Ekstrak Tumbuhan Obat, pp. 6-9, Direktorat Pengawasan Tradisional, Direktorat Jenderal Pengawasan Obat dan Makanan, Jakarta

Esfandiari, A. \& Kelly, A.P., 2005, 'The effects of tea polyphenolic compounds on hair loss amoung rodents', Journal of the National Medical Association. 97, 1165-1169.

Harborne, J.B., 1987, Metode Fitokimia, $2^{\text {nd }}$ ed, translated by Kosasih Padmawinata \& Iwang Soediro, pp. 147, Penerbit ITB, Bandung.

Harrison, S. \& Bergfeld, W., 2009, 'Diffuse hair loss: its triggers and management', Clev Clin J Med. 76, 361-367.

Lamria, E., 2013, 'Uji Stabilitas Fisik, Aktivitas, Dan Keamanan Dari Sediaan Hair Tonic Yang Mengandung Ekstrak Etanol Teh Hijau (Camellia sinensis L) sebagai Nutrasetika', Skripsi, Fakultas Farmasi Universitas, Jakarta.

Markham, K.R., 1988, Cara Mengidentifikasi Flavonoid, translated by Kosasih Padmawinata \& Sofi Niksolihin, pp. 65-75, Penerbit ITB, Bandung.

Tanaka, S., Saito, M. \& Tabata, M., 1980, 'Bioassay of Crude Drugs for Hair Growth Promoting 


\section{Hasyrul Hamzah}

Activity in Mice by a New Simple Method', Planta Medica Suppl. 1, 84-89.
Thorat, R., 2010, 'Herbal Treatment For Hair Loss', Int J Pharm Technol. 2, 497-503. 